\title{
Evangelização e promoção humana
}

\section{Evangelization and Human Promotion}

\section{Francisco de Aquino Júnior*}

\begin{abstract}
RESUMO
A problemática evangelização - promoção humana foi se desenvolvendo no processo lento e tenso de envolvimento da Igreja com as questões sociais, de reconciliação com o mundo moderno e de superação do dualismo natural X sobrenatural que culminou com o Concílio Vaticano II e foi assumindo novas dimensões e proporções no dinamismo eclesial por ele inaugurado. Ela adquiriu na Igreja latinoamericana particular relevância e centralidade e foi traduzida em termos de libertação, para além de sua formulação terminológica. De modo que uma adequada compreensão dessa problemática implica situá-la no processo mais amplo de renovação eclesial, explicitar sua especificidade latino-americana e, pelo menos, indicar, a modo de conclusão, a centralidade e as novas dimensões que ela adquire com o papa Francisco.
\end{abstract}

Palavras-chave: Evangelização. Promoção humana. América Latina. Libertação.

\section{ABSTRACT}

The binary evangelization - human promotion has developed within a process whose culmination was the Second Vatican Council and whose elements were: the Church's slow and tense engagement in social questions, the reconciliation with the modern world, the overcoming of the dualism natural vs. supernatural etc. This process, in turn, reached higher levels and bigger proportions within the ecclesial dynamism inaugurated by itself. In the Latin American Church this binary bore particular relevance and was translated in terms of liberation. Thus, a proper understanding of this binary means situating it in the context of a large process of ecclesial renewal, elucidating its Latin American specificity, and, by way of conclusion, at least briefly, alluding to the centrality as well as to the new dimensions that it has assumed in Pope Francis's pontificate.

Keywords: Evangelization. Human promotion. Latin America. Liberation.

\footnotetext{
* Doutor em teologia pela Westfälische Wilhelms-Universität; Münster (Alemanha). Professor de Teologia na Faculdade Católica de Fortaleza (FCF) e na Universidade Católica de Pernambuco (UNICAP). Presbítero da Diocese de Limoeiro do Norte-CE.<axejun@yahoo.com.br>.
} 


\section{INTRODUÇÃO}

Uma das características mais marcantes e impactantes das conferências episcopais latino-americanas é a insistência no vínculo constitutivo e essencial entre evangelização e promoção humana e em sua centralidade na missão da Igreja. Não se trata apenas de aceitar ou reconhecer que haja ou possa haver algum vínculo entre elas. Trata-se, antes e mais radicalmente, da insistência no caráter constitutivo e essencial desse vínculo e em sua centralidade na Igreja. De modo que sem promoção humana não se poderia falar propriamente de evangelização. Por mais que a evangelização não se esgote na promoção humana, essa é uma de suas dimensões constitutivas e essenciais.

Certamente, essa problemática do vínculo entre evangelização e promoção humana nem é exclusiva nem sequer surgiu na América Latina. Foi se desenvolvendo no processo lento e tenso de envolvimento da Igreja com as questões sociais, de reconciliação com o mundo moderno e de superação do dualismo natural X sobrenatural que culminou com o Concílio Vaticano II e foi assumindo novas dimensões e proporções no dinamismo eclesial por ele inaugurado. Mas ela adquiriu na Igreja latino-americana particular relevância e centralidade e, não obstante tensões e ambiguidades, foi traduzida em termos de libertação, para além de sua formulação terminológica.

De modo que uma adequada compreensão dessa problemática implica (1) situá-la no processo mais amplo de renovação eclesial, (2) explicitar sua especificidade latinoamericana e (3) pelo menos indicar, a modo de conclusão, a centralidade e as novas dimensões que ela adquire com o papa Francisco.

\section{PROCESSO DE RENOVAÇÃO ECLESIAL}

Não se pode entender a problemática da relação entre evangelização e promoção humana e sua formulação em termos mais ou menos dualistas (oposição ou justaposição) ou em termos estruturais (laços profundos, parte integrante, dimensão essencial e constitutiva) fora do contexto teológico-pastoral mais amplo de reconciliação da Igreja com o mundo moderno.

As relações Igreja e modernidade constituem um capítulo complexo e doloroso na história do Ocidente. As razões e as questões envolvidas nessa problemática são múltiplas e resistem a qualquer análise simplista apologética ou anatematizadora. Mas não há dúvida sobre o caráter tenso, polêmico e conflitivo dessa relação, do qual o caso Galileu Galilei (1564-1642) é apenas o exemplo mais famoso. Do ponto de vista da Igreja, o confronto com a modernidade atinge seu auge no século XIX, no contexto do processo de restauração em curso desde o Congresso de Viena em 1815², com a Encíclica Mirari Vos de Gregório XVI (1832) e a Encíclica Quanta Cura de Pio IX, acompanhada de um Sílabo ou coletânea de 80 proposições modernas consideradas inaceitáveis para um católico (1864). Elas apareciam e foram tomadas por muitos como uma condenação generalizada da modernidade e como sinal incontestável da incompatibilidade entre a doutrina católica e o mundo moderno. ${ }^{2}$

Paradoxalmente, o século XIX é marcado na Igreja também por um processo intenso e criativo de atuação pastoral que, não obstante seu caráter restauracionista e clerical ${ }^{3}$

\footnotetext{
${ }^{1}$ Cf. MATOS, H. C. J. Caminhando pela história da Igreja, vol. 2, p. 194-199.

${ }^{2}$ Cf. MATOS, H. C. J. Caminhando pela história da Igreja, vol. 3, p.13-25, 90-107; AUBERT, R. Nova história da Igreja, p.37-57; MARTINA, G. História da Igreja, p. 235-253.

${ }^{3}$ Cf. AUBERT, R. Nova história da Igreja, p. 127-140.
} 
e em meio a tensões entre correntes mais intransigentes e correntes mais liberais ${ }^{4}$, foi criando as condições que tornaram possível o processo de renovação eclesial e de reconciliação da Igreja com o mundo moderno que culmina com o Concilio Vaticano II.

Um capítulo importante nesse processo de reconciliação da Igreja com o mundo moderno e que tem um papel decisivo na problemática da relação entre evangelização e promoção humana é o chamado "catolicismo social" que se desenvolveu na Europa no contexto da revolução industrial e da situação da classe e do movimento operários nascentes ${ }^{5}$. É neste contexto que se insere a Encíclica Rerum Novarum do papa Leão XIII sobre a condição dos operários (1891). É a primeira intervenção oficial do magistério romano sobre a "questão social" e chegou a ser considerada como "carta magna" da atividade cristã no campo social (Pio XI) e como "texto fundador" da doutrina ou do ensino social da Igreja (Jean-Marie Mayeur). ${ }^{6}$ Ela pode ser tomada, em todo caso, como ponto de partida de uma tradição recente do pensamento social católico: Seja em relação ao magistério do Bispo de Roma que publicou uma série de encíclicas sociais por ocasião do aniversário desta encíclica; seja em relação ao desenvolvimento da reflexão social e teológica sobre questões sociais por parte de teólogos e cientistas católicos; seja, ainda, no que diz respeito à atuação de muitos católicos no campo social e político. Tudo isso vai se desenvolvendo ao longo do século XX, particularmente com a Ação Católica, e ganha novo impulso, novas perspectivas e novas dimensões com o Concílio Vaticano II e sua Constituição Pastoral Gaudium et Spes sobre a Igreja no mundo de hoje.

De fato, a problemática da relação Igreja-mundo está no centro das preocupações do Concílio: Constitui seu objetivo e sua marca fundamentais. Depois de séculos de hostilidade declarada, a Igreja se abre a um diálogo positivo com o mundo moderno, o que vai implicar numa nova auto compreensão da Igreja e de sua missão no mundo, como se pode comprovar logo no início do proêmio da Constituição Pastoral Gaudium et Spes que trata da solidariedade da Igreja com a família humana:

As alegrias e as esperanças, as tristezas e as angústias dos homens de hoje, sobretudo dos pobres e de todos os que sofrem, são também as alegrias e as esperanças, as tristezas e as angústias dos discípulos de Cristo. Não se encontra nada verdadeiramente humano que não lhes ressoe o coração $(G S 1)$

Esta solidariedade da Igreja com a família humana está intimamente ligada à sua missão de ser "sacramento" ou "sinal e instrumento" de salvação ou do reinado de Deus no mundo (Cf. $L G 1,9,48$ ). Certamente, a missão própria da Igreja é de "ordem religiosa". Mas, "desta mesma missão religiosa decorrem benefícios, luzes e forças que podem auxiliar a organização e o fortalecimento da comunidade humana segundo a lei de Deus" ( $G S 42)$. E aqui se pode compreender melhor a afirmação conciliar de que "o divórcio entre a fé professada e a vida cotidiana de muitos deve ser enumerado entre os erros mais graves de nosso tempo" e sua insistência em que não se deve criar "oposição artificial entre as atividades profissionais e sociais e a vida religiosa", pois "ao negligenciar os seus deveres temporais, o cristão negligencia os seus deveres para com o próximo e o próprio Deus e coloca em perigo a sua salvação eterna" (GS 43).

Embora com formulações ambíguas e até um tanto dualistas, o Concílio insiste em que não se pode separar nem muito menos contrapor "celeste e terrestre", "religioso

\footnotetext{
${ }^{4}$ Cf. MARTINA, G. História da Igreja, p. 147-209.

${ }^{5}$ Cf. MATOS, H. C. J. Caminhando pela história da Igreja, vol. 3, p. 114-129; AUBERT, Roger. Nova história da Igreja, p. 141-160.

${ }^{6}$ MAYEUR, J.-M. apud AUBERT, R. A Encíclica Rerum Novarum: ponto final de um lento amadurecimento. In: PONTIFÍCIO CONSELHO JUSTIÇA E PAZ. Da Rerum novarum à Centesimus annus, p. 7.
} 
e humano", "fé e vida", "Igreja e mundo", mesmo que tampouco se possa identificar sem mais um com o outro. Ele nega terminantemente uma oposição radical entre Igreja e mundo, embora deixe em aberto os termos da relação entre ambos ${ }^{7}$. E isso será provavelmente a questão teológica mais decisiva, mais complexa e mais conflitiva nos anos pós-conciliares, particularmente com as teologias da libertação ${ }^{8}$.

A partir daqui se pode compreender a insistência do magistério pós-conciliar na relação Igreja-mundo, concretamente na relação entre evangelização e promoção humana, embora a compreensão de promoção humana, o estatuto teórico de sua relação com a evangelização e os termos em que elas são formuladas tenha variado bastante, sobretudo por influência da Igreja latino-americana.

Na Encíclica Populorum Progressio sobre o desenvolvimento dos povos (1967), Paulo VI, em profunda sintonia com a "causa dos povos em via de desenvolvimento" ( $P P$ 5), formula a questão em termos de "desenvolvimento integral do homem" $\mathrm{e}$ "desenvolvimento solidário da humanidade" ( $P P$ 5), entendidos como "a passagem de condições menos humanas a condições mais humanas" (PP 20). E isto por fidelidade a Jesus Cristo e à missão de tornar presente o reinado de Deus no mundo, o que exige da Igreja "estar atenta aos sinais dos tempos e interpretá-los à luz do Evangelho" ( $P P$ 13).

O Sínodo dos bispos sobre A justiça no mundo (1971) se interroga sobre "a missão da Igreja na promoção da justiça no mundo" e afirma de modo claro e contundente: "A ação pela justiça e a participação na transformação do mundo aparecem-nos claramente como uma dimensão constitutiva da pregação do Evangelho, que é o mesmo que dizer, da missão da Igreja em prol da redenção e da libertação do gênero humano de todas as situações opressivas". E é condição de sua credibilidade, pois se "não mostra a sua eficácia na ação pela justiça no mundo, muito dificilmente ela será aceitável para os homens do nosso tempo".

A Exortação Apostólica Evangelii Nuntiandi do papa Paulo VI sobre a evangelização no mundo contemporâneo (1975) constitui um marco na compreensão e formulação da ralação entre evangelização e promoção humana: Seja enquanto maturação de uma reflexão em curso nas últimas décadas; seja enquanto ponto de referência fundamental para a reflexão posterior. Ao tratar do conteúdo da evangelização, fala, em sintonia com os bispos do chamado "terceiro mundo", de "uma mensagem de libertação" (EN 30) e da "necessária ligação com a promoção humana" (EN 31), insistindo que "entre evangelização e promoção humana - desenvolvimento, libertação - existem de fato laços profundos" (EN 31) sem, contudo, identificar sem mais "a libertação humana com a salvação em Jesus Cristo" (EN 35).

A questão é retomada e reafirmada em várias ocasiões e com diferentes formulações por João Paulo II. Já na Encíclica Redemptor hominis (1979) fala da "solicitude pelo homem, pela sua humanidade e pelo futuro dos homens sobre a face da terra e, por consequência, pela orientação de todo desenvolvimento e progresso, como um elemento essencial [da] missão [da Igreja]" (RH 16). Na Encíclica Sollicitudo rei socialis (1987) afirma que "o ensino e a difusão da doutrina social fazem parte da missão evangelizadora da Igreja", que o "ministério da evangelização em campo social" é "um aspecto do múnus profético da Igreja" (SS 41) e situa a "opção ou amor preferencial pelos pobres" entre "os temas e as orientações [...] repetidamente ventilados pelo Magistério nesses últimos anos" (SS 42). E na Encíclica Centesimus annus (1991) reafirma que "a doutrina social pertence à missão evangelizadora e faz parte essencial da mensagem cristã" e

\footnotetext{
Cf. AQUINO JÚNIOR, F. Questões fundamentais de teologia da libertação, p. 105-116.

${ }^{8}$ Cf. AQUINO JÚNIOR, F. Questões fundamentais de teologia da libertação, p. 261-262.
} 
insiste que a nova evangelização "deve incluir entre os seus componentes essenciais o anúncio da doutrina social da Igreja” ( $C A 5)$.

O Compêndio de Doutrina Social da Igreja retoma a problemática no capítulo intitulado "missão da Igreja e doutrina social", repetindo as afirmações fundamentais que se encontram nos documentos acima mencionados: "a doutrina social é parte integrante do ministério de evangelização da Igreja"; "entre evangelização e promoção humana há laços profundos"; "ensinar e difundir a doutrina social pertence à sua missão evangelizadora e faz parte essencial da mensagem cristã"; "não estamos na presença de um interesse ou de uma ação marginal, que se apõe à missão da Igreja, mas no coração mesmo da sua ministerialidade"; a missão da Igreja é de "ordem religiosa", mas dela "decorrem benefícios, luzes e forças que podem auxiliar a organização e o fortalecimento da comunidade humana segundo a lei de Deus" (CDSI 66-68).

E em sua Encíclica Deus caritas est, Bento XVI fala da caridade como um dos "âmbitos essenciais" da Igreja, "juntamente com a administração dos sacramentos e o anúncio da palavra": "praticar o amor para com as viúvas e os órfãos, os presos, os doentes e necessitados de qualquer gênero pertence tanto à sua essência como o serviço dos sacramentos e o anuncio do Evangelho" (DCE 22). E insiste, de modo um tanto ambíguo, que "a formação de estruturas justas não é imediatamente um dever da Igreja, mas pertence à esfera da política", enquanto "as organizações caritativas [...] constituem um seu opus proprium, um dever que lhe é congênito" (DCE 29).

É dentro desse panorama eclesial mais amplo que se pode compreender a centralidade, a especificidade e a formulação da problemática evangelização - promoção humana nas conferências dos CELAM. Sem esquecer, é claro, como advertimos acima, que esse panorama eclesial mais amplo foi profundamente influenciado e marcado pela Igreja latino-americana.

\section{ESPECIFICIDADE LATINO-AMERICANA}

Sem dúvida nenhuma, a problemática evangelização - promoção humana, formulada, sobretudo, em termos de opção preferencial pelos pobres e em perspectiva libertadora, constitui a marca mais expressiva e mais impactante da Igreja latino-americana nas conferências do CELAM. O Documento de Aparecida chega a afirmar explicitamente que "a opção preferencial pelos pobres é uma das peculiaridades que marca a fisionomia da Igreja latino-americana e caribenha".

Mas, dito isto, que é verdade, é preciso reconhecer a complexidade e mesmo as ambiguidades de sua compreensão e formulação nas diversas conferências. Isso vale particularmente em relação à conferência de Santo Domingo que marca certa ruptura com a perspectiva das conferências de Medellín e Puebla.

Convém revisitar o documento final das cinco conferências, indicando, por um lado, como tema aparece em cada uma delas e, por outro lado, identificando os traços comuns e as tensões e rupturas em sua compreensão e formulação.

\section{A) As cinco conferências}

É claro que não vamos fazer aqui um estudo amplo do documento das cinco conferências do CELAM. Sequer vamos tratar exaustivamente a temática evangeli-

${ }^{9}$ CELAM. Documento de Aparecida, n. 391. 
zação e promoção humana em cada uma delas. Vamos simplesmente indicar o lugar que a problemática ocupa na estrutura do documento e os termos em que ela é formulada.

\section{a) Conferência do Rio de Janeiro (1955)}

O mérito maior dessa Conferência foi certamente a decisão pela criação de um Conselho Episcopal Latino-americano para articular e coordenar as ações da Igreja em nível continental. Mas estamos ainda em tempos pré-conciliares e a preocupação fundamental da Igreja é com a "escassez de sacerdotes", com a "instrução religiosa" e com a "defesa da fé". Os títulos principais do Documento Final são muito reveladores nesse sentido: Vocações e formação do clero secular; Clero não nacional; Religiosos e religiosas; Auxiliares do clero; Organização da cura de almas; Meios especiais de propaganda; Protestantismo e movimentos anticatólicos: preservação e defesa da fé; Problemas sociais; Missões, índios e gente de cor; Imigração e povo do mar; Conselho Episcopal Latino-americano.

Os problemas sociais ocupam um lugar periférico nesta Conferência, mas não estão completamente ausentes. O título VIII do Documento Final está dedicado a essa questão. O texto expressa "profunda preocupação ante os problemas sociais da América Latina e a situação angustiante em que se encontra - apesar do acúmulo de bens que a Providência tem dispensado ao Continente - uma não pequena parte de seus habitantes" e destaca a "urgente necessidade de que todos os católicos colaborem com empenho para buscar, à luz da doutrina da Igreja, justa solução" (79). Reconhece a importância das obras de "caridade cristã" e das "diversas iniciativas e esforços que, inspirados nos princípios da justiça social, têm sido feitos para solucionar esses problemas, buscando, sobretudo, estabelecer a harmonia cristã entre capital e trabalho" (80). Reafirma a necessidade e urgência de "orientar e intensificar o trabalho social", priorizando "iniciativas dirigidas à própria raiz dos males que se hão de remediar" e "dando à ação social católica o espírito e as formas de coordenação comunitária que exige a gravidade da situação" (80). Chama atenção de todos os católicos "sobre as insídias e perigos das doutrinas marxistas e da propaganda do comunismo e sobre a necessidade de precaver-se e defender-se contra elas, principalmente ali onde estejam mais desenvolvidas" (83). E conclui manifestando "seu particular interesse pelo problema da elevação espiritual e social da população indígena" (84).

Na Declaração Final da Conferência, destaca-se ainda a "profunda e rápida transformação que se verifica nas estruturas sociais da América Latina devido ao intenso processo de industrialização" e a preocupação com a "necessidade de que o pensamento cristão, tão amiúde ausente dela, a esclareça e a anime" com "iluminação", com "educação" e com "ação". Reafirma com Pio XII que a difusão da doutrina social da Igreja é "necessária e obrigatória" e é "parte integrante do Evangelho e da moral cristã" e que "o laicato católico tem uma tarefa especial e insubstituível na animação e verificação do mundo socioeconômico"

A problemática da promoção humana, formulada em termos de "problemas sociais", "caridade cristã", "trabalho social", "ação social" ou "atividade social", aparece estreitamente vinculada à Doutrina Social da Igreja. É compreendida com Pio XII como "parte integrante do Evangelho e da moral cristã", sendo, portanto, "necessária e obrigatória". E, por isso, "deve ser incluída na catequese e ensinada sistemati-

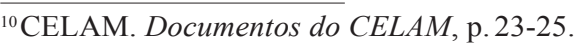


camente nos seminários, colégios e universidades, centos de ação social e de formação cristã" ${ }^{11}$.

\section{b) Conferência de Medellín (1968)}

A Conferência de Medellín inaugura e desencadeia oficialmente o processo de "recepção" do Concílio Vaticano II na América Latina e marca uma "nova etapa" na vida de nossa Igreja. Não sem razão, tem-se falado tanto de Medellín como um autêntico "pentecostes" na Igreja latino-americana. Se o Concílio abre a Igreja ao mundo e a compreende como sacramento de salvação; Medellín concretiza isso em um mundo marcado por profundas injustiças sociais e em processo crescente de tomada de consciência dessa situação e de organização e luta pela transformação da sociedade e em termos de libertação. Desta forma, sintoniza bem com o momento histórico do Continente e leva a sério o discernimento dos "sinais dos tempos", indicado pelo Concílio. Isso já aparece claramente no tema da Conferência: Presença da Igreja na atual transformação da América Latina.

O Documento Final, constituído por 16 textos, está organizado em três grandes partes: promoção humana, evangelização e crescimento da fé, Igreja visível e suas estruturas. Cada texto está estruturado segundo o método ver (fatos), julgar (fundamentação teológica) e agir (orientações pastorais).

Já na introdução, o Documento reconhece que a América Latina "vive um momento decisivo de seu processo histórico" e afirma que a Igreja "situou no centro de sua atenção o homem deste continente", consciente de que "para conhecer a Deus é necessário conhecer o homem”. Interpreta o "gigantesco esforço por uma rápida transformação e desenvolvimento como um evidente signo do Espírito que conduz a história dos homens e dos povos para sua vocação". E deixa claro que toda a reflexão da Conferência "orientou-se para a busca de forma de presença mais intensa e renovada da Igreja na atual transformação da América Latina, à luz do Concílio Vaticano II".

Embora haja toda uma seção articulada em torno do tema promoção humana (justiça, paz, família e demografia, educação, juventude), essa problemática perpassa de modo central e determinante o conjunto do Documento. De modo que não se trata, aqui, de um tema entre outros nem de um texto entre outros, mas da perspectiva geral e fundamental de todos os temas e de todos os textos. E essa perspectiva é compreendida em termos de libertação, para além das expressões com que isso é formulado. É verdade que Medellín foi profundamente marcado pela Constituição Pastoral Gaudium et Spes e pela Encíclica Populorum Pregressio e, por isso, é normal que a problemática da promoção humana apareça muitas vezes formulada em termos de transformação e/ou de desenvolvimento. Mas não se deve esquecer que uma das marcas mais importantes de Medellín foi traduzir a problemática da promoção humana (e suas diversas formulações) em termos de libertação, o que repercutirá, inclusive, em documentos posteriores do magistério romano como o Sínodo dos Bispos sobre a justiça no mundo (1971) e a Exortação Apostólica Evangelii nuntiandi (1975). Como bem afirma Dom Aloísio Lorscheider, "em Medellín, a teologia do desenvolvimento e da promoção humana cede lugar à teologia e pastoral da libertação" e, assim, "libertação", constitui a "palavra-chave" para se compreender Medellín ${ }^{12}$.

${ }^{11}$ CELAM. Documentos do CELAM, p. 24.

${ }^{12}$ LORSCHEIDER, A. Introdução. In: CELAM. Documentos do CELAM, p. 8. 


\section{c) Conferência de Puebla (1979)}

A Conferência Puebla se situa num contexto eclesial paradoxal. Por um lado, estamos no auge do desenvolvimento e maturação do dinamismo eclesial inaugurado por Medellín. Por outro lado, as tensões e os conflitos em torno desse dinamismo eclesial vêm crescendo e ganhando força na América Latina e no conjunto da Igreja. De modo que, embora Puebla confirme a perspectiva eclesial de Medellín, marca formalmente o início de um processo de ruptura e/ou de revisão eclesial que culminará em Santo Domingo $^{13}$. Por essa razão, Puebla deve ser tomada simultaneamente em continuidade e descontinuidade com Medellín.

Sua marca mais importante e decisiva é, sem dúvida nenhuma, a reafirmação da "clara e profética opção preferencial e solidária pelos pobres" feita por Medellín: “Afirmamos a necessidade de conversão de toda a Igreja para uma opção preferencial pelos pobres, no intuito de sua integral libertação" (1134). Aqui, especialmente, está o ponto que permite falar de continuidade com Medellín. Mas ele aparece com um duplo "não obstante" que indica certa descontinuidade ou, em todo caso, tensões em torno desse ponto central do dinamismo eclesial desencadeado por Medellín: "os desvios e interpretações com que alguns desvirtuaram o espírito de Medellín" e "o desconhecimento e até mesmo a hostilidade de outros" (1134). Já no discurso inaugural da Conferência, João Paulo II afirma que ela "deverá tomar como ponto de partida as conclusões de Medellín, com tudo o que tem de positivo, mas sem ignorar as incorretas interpretações por vezes feitas e que exigem sereno discernimento, oportuna crítica e claras tomadas de posição ${ }^{14 "}$.

Se Medellín foi uma "releitura" do Vaticano II e da Encíclica Populorum Progressio para a América Latina, Puebla foi, em boa medida, uma "releitura" latino-americana da Exortação Apostólica Evangelii Nunciandi, como indica o tema central da Conferência: Evangelização no presente e no futuro da América Latina.

O Documento final está organizado em cinco partes e segue em linhas gerais o método ver-julgar-agir: Visão pastoral da realidade latino-americana; Desígnio de Deus sobre a realidade latino-americana; Evangelização da Igreja da América Latina; Igreja missionária a serviço da evangelização na América Latina; Sob o dinamismo do Espírito: opções pastorais.

A problemática da promoção humana ocupa lugar central nas preocupações e no Documento Final de Puebla e aparece de modo mais explícito e sistemático num capítulo que trata da evangelização, em um tópico intitulado "evangelização, libertação e promoção humana". Aparece formulada em termos de libertação integral: libertação de todas as formas de pecado e libertação para a comunhão com os homens e com Deus, libertação que vai se realizando na história, libertação evangélica e com meios evangélicos (Cf. 480ss). E aparece vinculada à Doutrina Social da Igreja (Cf. 472ss), como "parte integrante" do seguimento de Jesus Cristo e da evangelização (Cf. 476, 1254). A própria ação evangelizadora aparece formulada em termos de "evangelização libertadora" (491ss). Isso mostra que apesar das tensões, ponderações e reticências o espírito de Medellín continua muito vivo em Puebla.

\section{d) Conferência de Santo Domingo (1992)}

A Conferência de Santo Domingo marca uma nova etapa na Igreja latino-americana. Ela é o ponto auge de um processo de correção ou reorientação pastoral em curso

\footnotetext{
${ }^{13} \mathrm{Cf}$. LORSCHEIDER, A. Mantenham as lâmpadas acesas, p. 74-94.

${ }^{14} \mathrm{JOÃO}$ PAULO II. Conclusões da Conferência de Puebla, p. 16.
} 
desde a década de 1970. Clodovis Boff formulou isso em termos de "ajuste pastoral", indicando com essa expressão "um redirecionamento geral da pastoral na América Latina e Caribe":

Com 'ajuste pastoral' entendemos a retomada do caminho já tradicional da Igreja latino-americana, mas dando-lhe uma outra direção, uma direção não contrária, mas diferente da estabelecida. Na verdade, trata-se de um direcionamento global. Por ele, os bispos reassumem a caminhada que vem de Medellín, mas num outro contexto e por isso com outra sensibilidade, numa outra ótica [...]: Primeiro, [...] reforça a Igreja-hierarquia, enfraquecendo a Igreja-Povo de Deus. Segundo, $[\ldots]$ privilegia a dimensão propriamente evangelizadora da Igreja, enfatiza sua função especificamente religiosa e missionária [...], mas [...] não de modo a radicalizar a missão social da Igreja, mas antes a relativizá-la. Ou seja, a reorientação para o religioso parece se fazer às custas do social [...]. Santo Domingo é a música latino-americana, tocada com guitarra romana ${ }^{15}$.

Esta conferência se realiza no contexto da celebração dos 500 anos de evangelização na América Latina e no espírito da "nova evangelização" proposta pelo papa João Paulo II, como afirma claramente o Documento Final (Cf. 22) e a mensagem final enviada aos povos do Continente:

A IV Conferência [...] quis marcar as linhas-mestras de um novo impulso evangelizador, que ponha Cristo no coração e nos lábios, na ação e na vida de todos os latino-americanos. Nossa tarefa é esta: fazer com que a verdade sobre Cristo, a Igreja e o homem penetre mais profundamente em todos os estratos da sociedade, buscando sua progressiva transformação. A nova evangelização foi a ideia central de todo o nosso trabalho ${ }^{16}$.

É claro que Santo Domingo se afirma em "continuidade" com as conferências anteriores (Cf. 1, 290) e confirma a "opção preferencial pelos pobres": uma opção "firme e irrevogável, mas não exclusiva nem excludente" (Cf. 178, 296). E é claro que a problemática da "promoção humana" tem um lugar de destaque na Conferência: é um dos temas centrais (evangelização, promoção humana, cultura cristã), assume novas dimensões (Cf. 164-209) e aparece como "parte da missão evangelizadora" (158). Mas já não tem a centralidade que tinha em Medellín e Puebla nem é mais compreendida e proposta em termos de libertação. A "nova evangelização" tem um enfoque essencialmente "religioso" e "doutrinal" e a "promoção humana" é formulada mais em termos ético-culturais. Expressões do tipo "libertação", "libertador", "oprimido", “opressão" foram praticamente eliminadas ${ }^{17}$. Segundo Francisco Catão, já "a escolha da expressão promoção humana manifesta a preocupação de não envolver a Igreja, como tal, nos processos históricos de transformação social, econômica e polícia”, indicando a "prevalência do enfoque ético" na ação da Igreja: unidade, mentalidade, princípios, cultura de solidariedade ${ }^{18}$.

\section{e) Conferência de Aparecida (2007)}

A Conferência de Aparecida pode ser situada entre Medellín/Puebla e Santo Domingo. Não aprofunda a ruptura de Santo Domingo e, em certo sentido, retoma e

\footnotetext{
${ }^{15}$ BOFF, C. O Evangelho de Santo Domingo, p. $26 \mathrm{~s}$.

${ }^{16}$ CELAM. Conclusões da IV Conferência do Episcopado Latino-americano, p. 47.

${ }^{17} \mathrm{Cf}$. BOFF, C. O Evangelho de Santo Domingo, p. 27-29.

${ }^{18}$ CATÃO, F. Santo Domingo, p. 35-45.
} 
sintoniza melhor com o dinamismo eclesial de Medellín e Puebla. Por isso, foi saudada com certo entusiasmo pelos setores eclesiais mais afinados com essa tradição.

Os tempos são outros e o cenário eclesial é profundamente marcado pelo projeto de "nova evangelização" proposto por João Paulo II: uma evangelização mais centrada nas questões explicitamente religiosas (culto e doutrina) e uma perspectiva de atuação social de cunho mais ético-cultural que sócio-político. Em todo caso, Aparecida tem um tom mais dialogal e conciliador. Não soa tanto como ruptura e parece melhor articulada com a tradição Medellín/Puebla:

A V Conferência do Episcopado Latino-americano e Caribenho é novo passo no caminho da Igreja, especialmente a partir do Concílio Ecumênico Vaticano II. Ela dá continuidade e, ao mesmo tempo, recapitula o caminho de fidelidade, renovação e evangelização da Igreja latino-americana ao serviço de seus povos, que se expressou oportunamente nas Conferências Gerais anteriores (9).

Aparecida retoma o método ver-julgar-agir (Cf. 19) que havia sido abandonado em Santo Domingo. O Documento Final está organizado em três partes: A vida de nossos povos; a vida de Jesus Cristo nos discípulos missionários, a vida de Jesus Cristo para nossos povos. Discipulado-missionariedade é o núcleo teológico em torno do qual se desenvolve a reflexão sobre a vida e missão da Igreja. Isso permitiu retomar e explicitar com Bento XVI o fundamento cristológico da opção pelos pobres: “A opção preferencial pelos pobres está implícita na fé cristológica naquele Deus que se fez pobre por nós, para nos enriquecer com sua pobreza" (392).

A problemática da promoção humana aparece formulada indistintamente em termos de "opção preferencial pelos pobres", "libertação cristã", promoção/libertação "integral", "caridade", "solidariedade", "pastoral social" e com enfoque mais teológicopastoral que ético. E aparece sempre vinculada à missão da Igreja: "A evangelização vai unida sempre à promoção humana e à autêntica libertação cristã" (26); a evangelização "inclui a opção preferencial pelos pobres, a promoção humana integral e a autêntica libertação cristã" (146); "todo processo evangelizador envolve a promoção humana e a autêntica libertação" que "deve ser integral, isto é, promover todos os homens e o homem todo" (399); O serviço da caridade é "expressão irrenunciável da própria essência" da Igreja (399); "não se pode separar [a missão evangelizadora] da solidariedade com os necessitados e da sua promoção humana integral" (550).

O tema aparece de modo mais sistemático na III parte em um capítulo intitulado "reino de Deus e promoção da dignidade humana". Embora situado na parte que trata do agir, o texto está mais centrado na fundamentação teológica do compromisso da Igreja com a promoção humana do que nos caminhos concretos de efetivação desse compromisso: Reino de Deus, justiça social e caridade cristã; a dignidade humana; a opção preferencial pelos pobres e excluídos; uma renovada pastoral social para promoção humana integral; globalização da solidariedade e justiça internacional; rostos dos sofredores que doem em nós (Cf. 380-430).

\section{B) Unidade, tensões e rupturas nas cinco conferências}

Conforme indicamos no início do texto e demonstramos no tópico anterior, a insistência no vínculo constitutivo e essencial entre evangelização e promoção humana e sua centralidade na missão da Igreja é, sem dúvida, uma das características mais marcantes e mais impactantes das conferências do CELAM. Isso fez, inclusive, com 
que a Igreja latino-americana desempenhasse um papel fundamental na compreensão, formulação e dinamização dessa problemática no conjunto da Igreja.

Mas é preciso reconhecer que a compreensão e formulação dessa problemática nas cinco conferências são muito mais complexas do que pode parecer. Varia bastante de conferência para conferência. Seja no que diz respeito à compreensão de "promoção humana", seja no que diz respeito à sua importância e ao seu lugar na "evangelização".

Quanto à compreensão de promoção humana, é visível a diferença entre Medellín/ Puebla e Santo Domingo. E para além das expressões com que é formulada. Em Medellín e Puebla, ela compreendida em termos de libertação e abordada numa perspectiva de cunho mais sócio-político. Em Santo Domingo, ela é compreendida mais em termos de promoção e abordada fundamentalmente numa perspectiva ético-cultural. E isso tem muitas implicações pastorais, pois enquanto uma abordagem sócio-política é muito sensível e atenta à problemática das mediações históricas, uma abordagem ético-cultural tende a centrar-se mais em valores e princípios sem levar muito à sério a problemática das mediações históricas. A primeira tem um caráter mais prático e gera um dinamismo pastoral de inserção da Igreja nos processos sociais. A segunda tem um caráter mais teórico e gera um dinamismo pastoral de cunho mais doutrinal, principialista e abstrato. Já Aparecida, como indicamos acima, tenta articular as duas perspectivas (sócio-política e ético-cultural) e, dessa forma, não só ameniza a ruptura de Santo Domingo, mas esboça ou ao menos aponta para uma nova síntese que será desenvolvida pelo papa Francisco - que fez parte da comissão de redação do texto.

Quanto à relação entre evangelização e promoção humana, todas as conferências afirmam, em sintonia com o magistério romano, que a promoção humana é dimensão ou aspecto ou elemento ou parte integrante e essencial da evangelização. Não só tem a ver com a evangelização, mas tem a ver de modo constitutivo e essencial. Isso é comum a todas as conferências. Mas, enquanto Medellín e Puebla, no espírito conciliar de uma Igreja descentrada e voltada para os grandes problemas da humanidade, faz da promoção ou libertação humana o centro de sua ação evangelizadora; Santo Domingo, no espirito da "nova evangelização" proposta por João Paulo II, põe no centro de suas preocupações as questões mais explicitamente religiosas e institucionais (culto, doutrina, hierarquia). Certamente, Santo Domingo não nega a importância essencial da promoção humana, como Medellín e Puebla não negam a importância essencial das questões mais explicitamente religiosas e institucionais. Mas o centro em torno qual se articula o projeto evangelizador é bem distinto nos dois casos. Aparecida assume também aqui uma posição muito peculiar. A insistência no vínculo essencial "discípulosmissionários", de cunho mais teológico que moral e de base mais bíblica que doutrinal, ajuda a recuperar a centralidade dos problemas humanos em geral e dos pobres em particular na missão evangelizadora da Igreja. Isso se articula melhor com perspectiva de Medellín e Puebla e terá, ademais, uma importância muito grande para o conjunto da Igreja por ser um texto de referência do papa Francisco que, como indicamos acima, esteve na comissão de redação desse documento.

De modo que a problemática "evangelização e promoção humana" nas conferências do CELAM é muito mais complexa do que parece e resiste aos simplismos reducionistas de radical identidade (hermenêutica da continuidade) ou ruptura radical (hermenêutica da descontinuidade). E deve ser tomada em sua relação tensa e criativa com o magistério romano que, por um lado, influenciou decisivamente as cinco conferências, como se pode ver nos seus documentos finais (acento, perspectiva, linguagem), mas, por outro lado, foi influenciado pela compreensão e formulação que foi adquirindo na Igreja latino-americana. 


\section{CONCLUSÃO: NOVAS PERSPECTIVAS COM O PAPA FRANCISCO}

Convém concluir esse estudo sobre a relação "evangelização - promoção humana" nas conferências do CELAM ao menos indicando as novas perspectivas que ela adquire com o papa Francisco. Seja porque estas novas perspectivas estão muito ligadas à caminhada latino-americana; seja porque repercutirá positiva e criativamente sobre ela, confirmando-a e alargando seus horizontes.

Seu mérito maior consiste em dar nova centralidade a essa questão na missão da Igreja e em esboçar ou ao menos apontar para uma nova síntese da problemática que desenvolva e integre melhor questões e aspectos que vinham aparecendo nos últimos tempos e articule melhor questões e aspectos aparentemente contraditórios.

Em sintonia com o Concílio Vaticano II e as Conferências de Medellín e Puebla, Francisco confere nova centralidade à relação "evangelização - promoção humana". No centro de suas preocupações e orientações pastorais estão os grandes problemas da humanidade e as diversas formas de injustiça e sofrimento. Sua crítica constante ao clericalismo e à autoreferencialidade da Igreja e sua insistência em uma "Igreja em saída para as periferias" ou "Igreja pobre e para os pobres" sintoniza com e atualiza as grandes intuições eclesiológico-pastorais do Concílio Vaticano II e das Conferências de Medellín e Puebla: Igreja povo de Deus - sacramento de salvação ou do reinado de Deus no mundo; Igreja dos pobres, salvação como libertação/misericórdia.

Além do mais, Francisco assume e desenvolve questões ou aspectos que vinham sendo indicados e esboçados nos últimos tempos: questões culturais, questões urbanas, questões existenciais, questões ambientais etc. E faz isso de tal modo que articula numa síntese complexa e dinâmica questões aparentemente inconciliáveis: existencial - social; cultural - político, antropológico - ambiental, micro - macro, conversão do coração - transformação das estruturas etc. Basta ver como essa problemática aparece em sua Exortação Apostólica Evangelii Gaudium sobre o anúncio do Evangelho no mundo atual e em sua Carta Encíclica Laudo si' sobre o cuidado da casa comum. Sem falar de seus encontros com os movimentos populares que recupera e reafirma na Igreja a importância e necessidade de mediações históricas concretas na efetivação da justiça social, para além de princípios e ideais meramente abstratos.

Tudo isso confere nova atualidade à problemática "evangelização - promoção humana" na Igreja alarga seus horizontes e desafia toda a Igreja na vivência/anúncio da alegria do Evangelho no cuidado da casa comum.

\section{REFERÊNCIAS}

AQUINO JÚNIOR, Francisco de. Questões fundamentais de teologia da libertação. 2016. (Perspectiva Teológica, 48). . Nas periferias do mundo: Fé - Igreja - Sociedade. São Paulo: Paulinas, 2017.

AUBERT, Roger. Nova história da Igreja: A Igreja na sociedade liberal e no mundo moderno. Petrópolis: Vozes, 1975. Tomo I.

A Encíclcica Rerum Novarum: ponto final de um lento amadurecimento. In: PONTIFICIO CONSELHO JUSTIÇA E PAZ. Da Rerum novarum à Centesimus annus: Texto completo das duas encíclicas com dois estudos de Roger Aubert e Michel Schooyans. São Paulo: Loyola, 1993. p. 7-28.

BENTO XVI. Carta Encíclica Deus caritas est. São Paulo: Paulinas, 2008.

BOFF, Clodovis. O Evangelho de Santo Domingo: Os dez temas-eixos do Documento da IV CELAM. Petrópolis: Vozes, 1994.

CATÃO, Francisco. Santo Domingo: Significação e Silêncios. São Paulo: Paulinas, 1993. 
CELAM. Documentos do CELAM: Rio - Medellín - Santo Domingo. São Paulo: Paulus, 2004.

. Mensagem da IV Conferência aos povos da América Latina e do Caribe. In: CELAM. Conclusões da IV Conferência do Episcopado Latino-americano: Texto Oficial. São Paulo: Paulinas, 1992.

. Documento de Aparecida: Texto conclusivo da V Conferência Geral do Episcopado Latinoamericano e do Caribe. São Paulo: Paulinas, 2007.

JOÃO PAULO II. Discurso Inaugural pronunciado no seminário palafoxiano de Puebla de Los Angeles, México. In: CELAM. Conclusões da Conferência de Puebla: Texto oficial. São Paulo: Paulinas, 1986.

. Carta Encíclica Redemptor hominis. São Paulo: Paulinas, 1979.

. Carta Encíclica Sollicitudo rei socialis. São Paulo: Paulinas, 1990.

. Carta Encíclica Centesimus annus. São Paulo: Paulinas, 2007.

LORSCHEIDER, Aloísio. “Introdução”. In: CELAM. Documentos do CELAM: Rio - Medellín Santo Domingo. São Paulo: Paulus, 2004.

. Mantenham as lâmpadas acesas: Revisitando o caminho, recriando a caminhada. Fortaleza: Edições UFC, 2008.

MARTINA, Giacomo. História da Igreja: De Lutero aos nossos dias. Vol. 3. A era do liberalismo. São Paulo: Loyola, 1996.

MATOS, Henrique Cristiano José. Caminhando pela história da Igreja: Uma orientação para iniciantes. Vol. 2. Belo Horizonte: Lutador, 1995.

Lutador, 1996.

Caminhando pela história da Igreja: Uma orientação para iniciantes. Vol. 3. Belo Horizonte:

PONTIFÍCIO CONSELHO “JUSTIÇA E PAZ”. Compêndio da Doutrina Social da Igreja. São Paulo: Paulinas, 2011.

PAULO VI. Carta Encíliclia Populorum Progressio sobre o desenvolvimento dos povos. São Paulo: Paulinas, 1990.

PAULO VI. Exortação Apostólica Evangelii Nuntiandi sobre a evangelização no mundo contemporâneo. São Paulo: Paulinas, 1976.

PIO XI. Radiomensagem na solenidade de Pentecostes: 50 aniversário da Carta Encíclica "Rerum Novarum" de Leão XIII. 1 jun. 1941. Disponível em: <https://w2.vatican.va/content/pius-xii/pt/ speeches/1941/documents/hf_p-xii_spe_19410601_radiomessage-pentecost.html>. Acesso em: 15 abr. 2018 .

SÍNODO DOS BISPOS. A justiça no mundo. Disponível em: < http://www.vatican.va/roman_curia/ synod/documents/rc_synod_doc_19711130_giustizia_po.html>. Acesso em: 12 maio 2018.

Recebido: 27/06/2018

Aprovado: 09/07/2018

Correspondência para:

Francisco de Aquino Júnior

Caixa Postal, 27

62930-000 Limoeiro do Norte, CE, Brasil 